九州大学学術情報リポジトリ

Kyushu University Institutional Repository

\title{
Does Urban Concentration Mitigate the Negative Impacts of Electric Energy Consumption on Climate Change? Evidence from Egypt
}

Osman, Taher

Faculty of Urban and Regional planning, Cairo University

Salem, Muhamed

Faculty of Urban and Regional planning, Cairo University

https://doi.org/10.5109/4102480

出版情報: Proceedings of International Exchange and Innovation Conference on Engineering \& Sciences (IEICES). 6, pp.141-148, 2020-10-22. Interdisciplinary Graduate School of Engineering Sciences, Kyushu University バージョン:

権利関係 : 


\title{
Does Urban Concentration Mitigate the Negative Impacts of Electric Energy Consumption on Climate Change? Evidence from Egypt
}

\author{
Taher Osman, Muhamed Salem \\ Faculty of Urban and Regional planning, Cairo University \\ Corresponding author email: taher@kyudai.jp
}

\begin{abstract}
This paper researched the impacts of the built environment on local electricity consumption in metropolitan areas through a contextual investigation of Giza Governorate in Greater Cairo Metropolitan Region (GCMR), Egypt. Basic Equation Modeling was used for the investigation on the causality of residential utilizations of power. The impacts of significant drivers theoretically causing the local vitality utilization, for example, family sociosocioeconomics, family perspectives, family unit responsibility for, and assembled condition were inspected. Main results were the built environment associated to a settlement such as number of rooms and floor area in the settlement considerably influences the domestic electricity consumption; and the population density has considerable positive influences on the domestic electricity consumption. Findings of this paper propose that a design of built environment could take part in managing the domestic energy consumption in developing metropolitan regions which could be an effective tool to adapt the climate change ultimately.
\end{abstract}

Keywords: Climate Change, Built Environment, Urban characteristics, Electricity consumption, Developing Countries.

\section{INTRODUCTION}

Strategy producers have understood that without noteworthy decreases in the power request, and huge increments in the vitality proficiency of the local division, it will be difficult to bring down carbon dioxide (CO2) discharges and alleviate the dangers of worldwide environmental change [1] [2] [3]. To help educated choices about how to decrease power use and $\mathrm{CO} 2$ discharges from the lodging area, it is basic to know which drivers impact residential power utilization. Over the half of total populace are right now settling in metropolitan regions where over $70 \%$ of the vitality is expended [4] [5] [6]. The gigantic urban populace with escalated vitality request in the metropolitan territory causes provincial scale natural issues, for example, air contamination, water contamination, and flooding while it would likewise prompt the worldwide scale ecological issues, for example, the environmental change [7] [8] [3]. These natural issues have been attracting more consideration urban zones especially in creating world, since over $90 \%$ of future urban populace development is relied upon to happen in creating metropolitan districts [4].

Based on that, the top highlighted questions now a days regarding the environmental issues in the developing metropolitan areas is how a sustainable energy consumption pattern could be achieved in the metropolitan area. Urban planners typically assume that design and location of residential areas, which are often described as built environment, have significant associations with domestic's energy consumption of housing and transportation [9] [10]. The main purposes of these studies are to specify which built environment drivers contribute to domestic energy consumption and to quantify to what extent these drivers' impact on it. The studies have provided an important basis for the urban planning, especially in advanced metropolitan regions, where a compact urban design is often

Highlighted and promoted as a sustainable urban form [9] [11]. Past examination has demonstrated that building factors alone clarify at any rate $40 \%$ of the inconstancy in vitality use, as summed up beneath. In any case, not the entirety of the structure indicators regularly inspected can be affected on through vitality productivity retrofits. Different elements, for example, practices, are additionally broadly considered to large affect vitality utilization and are in like manner the subject of intercessions, for example, input and utilization of normal practices.

\subsection{Impact of built environment on energy consumption}

Built environment attributes have been viewed as one of the basic drivers of vitality utilization; $70 \%$ of the vitality expended in city is identified with the built environment drivers [9] [12]. The built environment is featured on the grounds that it could be possibly overseen through urban arranging. A lion's share of the current examinations exploring the connection between built environment and vitality utilization have concentrated on the transportation-related vitality utilization instead of in-house vitality utilization [13]. With respect to the in-house vitality utilization contemplates featuring the impacts of built environment on in-house vitality utilization, Guerra-Santin and Itard [12] examined the drivers that impact private warming utilization, and uncovered that while drivers, for example, family unit size didn't altogether impact warming utilization. Ewing and Rong [13] identified three paths through which urban form influence domestic electricity consumption. The first is directly through electric transmission and distribution loss, with relatively small impact. The second is indirectly through housing stock, such as types and size of residence, which has impact on electricity consumption. The third is also indirectly through formation of the urban heat island, which interestingly revealed that though very small, the residents in compact residential areas and those living in sprawl areas differs in energy consumption, partly because of the difference of the 
needs for space heating or cooling, given the urban heat island effect.

\subsection{Impact of household characteristics on energy consumption}

Lou et al. [18] contemplated the determinants of power interest for energized low-salary family units in a rustic site in South Africa. They utilized an econometric relapse model, metered power utilization information, financial overview information and gadget proprietorship information gathered in 2001 and 2002 were broke down to decide the drivers of power utilization inside these family units. Additionally, Tiwari [19] built up a relapse model utilizing a family unit review embraced in 1987-1988 by the Bombay Metropolitan Regional Development Authority, which remembered an aggregate of 6358 homes for Bombay, India .The investigation dissected the impact of abiding, financial and gadget related drivers on yearly power utilization. O'Doherty et al. [14] did a study on staying attributes and issues and family unit individuals in 40,000 families in Ireland (National Survey on Housing Quality - NSHQ). The study remembered information for the principle power expending apparatuses.

The social determinants of expected electricity value, pay, training, enrollment of a minority gathering, work of mates, if respondent is under 35 , the nearness of a newborn child (under 3 ), the nearness of an older inhabitant (more than 65), number of individuals matured 3-18, number of individuals beyond 185 years old, environmentalism scale included 5 things. Vitality information scale was made based fair and square of the member's information on vitality utilization. Vitality information scale had the option to clarify $34 \%$ and the consolidated model of building and social determinants had the option to clarify $58 \%$ of the difference in summer electricity utilization. In the social determinants model, salary (expanding electricity use), enrollment of a minority gathering (diminishing electricity use), number of individuals matured 3-18 (expanding electricity utilization), number of individuals of beyond 18 years old (expanding impact), warm solace scale (expanding electricity use), and vitality information scale (expanding electricity use) were critical. In the joined model, pay (expanding electricity use), respondent age (diminishing electricity utilization) and warm solace scale (expanding electricity use) were noteworthy.

\subsection{Impact of Appliance types on Energy consumption}

Machine proprietorship and size are end up being noteworthy indicators of electricity utilization. The machine file of Cramer et al. [11], included number, recurrence of utilization, and area in staying, distributed proficiency, and assessed irregularity factor. The machine record of Tiwari [19], depended on responsibility for apparatus and the force information. Leahy and Lyons [23] applied a standard direct least squares relapse utilizing Irish Household Budget Survey information. Extra cash, family size, staying age and financial gathering were among the factors that were appeared to impact electricity utilization in the home. A variation of the measurable/relapse approach is a Conditional Demand Model (CDA) first created by Parti and Parti [24]. Month to month electricity bills over a yearly period were relapsed against machine proprietorship figures and segment factors, for example, family unit salary and number of inhabitants to disaggregate electricity request into 16 distinctive endemployments. This system demonstrated the high essentialness of apparatus responsibility for utilization designs over a $24 \mathrm{~h}$ period.

The point of this paper is to research the built environment, family unit qualities, and Appliance types related drivers that have noteworthy or non-critical consequences for residential electricity utilization, and to recognize which singular indicators have the best effect on vitality utilization. The discoveries are critical to (1) comprehend which factors should be estimated to comprehend vitality utilization, and (2) to shape intercessions with the best expected effect.

\section{METHOD AND DATA}

\subsection{Study Area}

The target area of this paper is Greater Cairo Metropolitan Region (GCMR), It is classified as a metropolitan region, with over 20 million population, and has been becoming as one of the global metropolitan regions representing Africa. The population has been still growing at a high growth rate [27] [28]. The sub-urbans of GCMR obliges numerous relocations from everywhere throughout the nation while the populace overflows significantly from the customary urban regions to nearby zones [29] [6]. They have prompted the ascent of lodging request both in urban center and fringe regions. Houses have been created through a recharging of ordinary urban houses though horticultural land has been progressively changed into private use in the country zone. Osman et al., 2016 [27] explained that these ongoing elements of lodging improvement in GCMR have made a few people in the new lodging territories follow an advanced way of life with a family unit, as differentiating to the conventional way of life living respectively with a more distant family. Numerous previous explores, for example, M El Araby [30] and Yin et al. [31] called attention to the potential environmental disintegration that went with the high financial development, quick increment of urban populace, and an adjustment in person's inclination into the utilization arranged way of life add to the expansion of vitality utilization in GCMR.

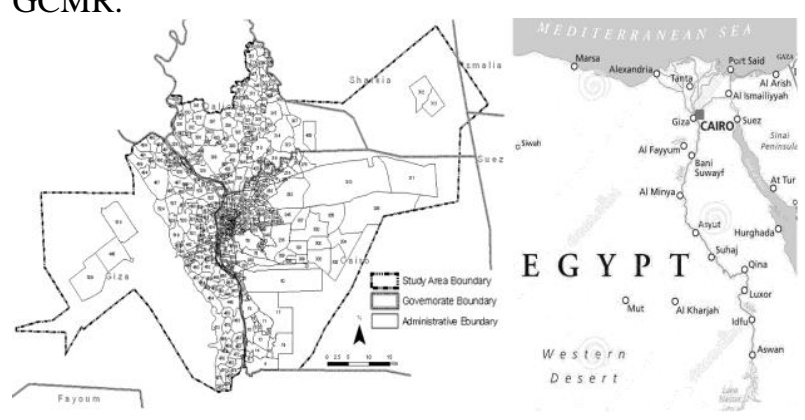

Fig. 1. Greater Cairo Metropolitan Region Location in Egypt. 


\subsection{Dataset}

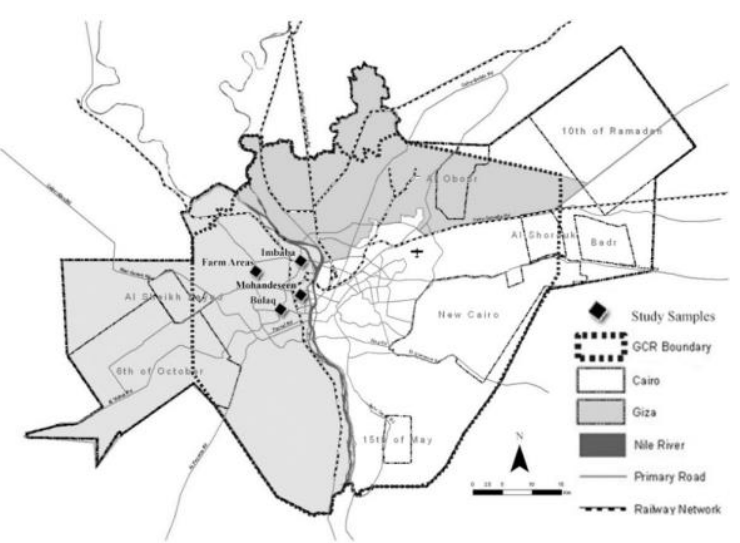

Fig. 2. Study Samples.

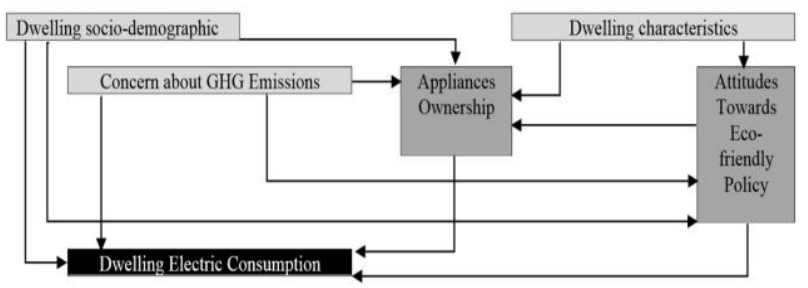

\subsubsection{Local Survey}

A nearby study was structured and directed by an examination group from Cairo University including the creators of this paper. A poll was intended for a meeting put together family overview with respect today by day exercises to acquire socio-segment information and assessments identified with way of life. The poll sheets comprised of six sections: individual qualities, family unit traits, a person's day by day practices, the family unit's everyday practices, information from a person's movement journal, and a person's qualities. With respect to the individual traits, the respondents were mentioned to give essential data, for example, sexual orientation, age, occupation, origination, and instruction level. They were likewise posed inquiries about their family unit's characteristics, including pay, settlement, responsibility for, and data about any employed house cleaner. Next, the respondents were gotten some information about their everyday utilization, and network-based exercises, alongside family unit-based practices, for example, merchandise utilization, joint recreation exercises, and shopping.

\subsubsection{Descriptive Statistics of Respondents}

Fig. 3. Study Hypothetical Model [3].

Table 1. Descriptive Statistics of Survey Respondents' Households in Giza (N=900)

\begin{tabular}{|c|c|c|c|c|c|c|c|c|}
\hline $\begin{array}{l}\text { Number } \\
\text { of children }\end{array}$ & 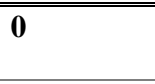 & 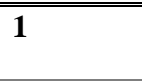 & 2 & 3 & 4 & 5 & $6<$ & \\
\hline Percentage & $11.9 \%$ & $31.10 \%$ & $29.40 \%$ & $19.30 \%$ & $6.80 \%$ & $1.20 \%$ & $0.30 \%$ & \\
\hline $\begin{array}{l}\text { Monthly } \\
\text { household } \\
\text { income (EGP) }\end{array}$ & $<600$ & $600-900$ & $900-1200$ & $1200-1500$ & $\begin{array}{l}1500- \\
1800\end{array}$ & $\begin{array}{l}1800- \\
2400\end{array}$ & $2400<$ & \\
\hline Percentage & $4.70 \%$ & $19.40 \%$ & $27.30 \%$ & $29.90 \%$ & $9.50 \%$ & $6.30 \%$ & $2.90 \%$ & \\
\hline Car ownership & 0 & 1 & 2 & $3<$ & & & & \\
\hline Percentage & $98.10 \%$ & $1.70 \%$ & $0.20 \%$ & $0.00 \%$ & & & & \\
\hline $\begin{array}{l}\text { Motorbike } \\
\text { ownership }\end{array}$ & 0 & 1 & 2 & $3<$ & & & & \\
\hline Percentage & $39.40 \%$ & $49.10 \%$ & $9.70 \%$ & $1.80 \%$ & & & & \\
\hline $\begin{array}{l}\text { Air-conditioner } \\
\text { ownership }\end{array}$ & 0 & 1 & 2 & $3<$ & & & & \\
\hline Percentage & $97.30 \%$ & $2.30 \%$ & $0.30 \%$ & $0.10 \%$ & & & & \\
\hline \multirow{2}{*}{ Gender } & Male & Female & & & & & & \\
\hline & $52.40 \%$ & $47.60 \%$ & & & & & & \\
\hline \multirow[t]{2}{*}{ Education } & No school & Primary & $\begin{array}{l}\text { Junior } \\
\text { high }\end{array}$ & Senior high & Academy & $\begin{array}{l}\text { Universit } \\
\mathrm{y}\end{array}$ & & \\
\hline & $1.20 \%$ & $28.60 \%$ & $29.70 \%$ & $33.80 \%$ & $3.90 \%$ & $2.80 \%$ & & \\
\hline \multirow[t]{2}{*}{ Age } & $16-19$ & $20-29$ & $30-39$ & $40-49$ & $50-59$ & $60-69$ & $70<$ & \\
\hline & $2.30 \%$ & $28.30 \%$ & $32.80 \%$ & $21.30 \%$ & $13.60 \%$ & $1.30 \%$ & $0.40 \%$ & \\
\hline \multirow[t]{4}{*}{ Occupation } & $\begin{array}{l}\text { Governme } \\
\text { nt } \\
\text { officer }\end{array}$ & $\begin{array}{l}\text { Housewif } \\
\text { e }\end{array}$ & $\begin{array}{l}\text { Authorize } \\
\text { d self- } \\
\text { employme } \\
\text { nt }\end{array}$ & $\begin{array}{l}\text { Unauthoriz } \\
\text { ed self- } \\
\text { employmen } \\
\text { t }\end{array}$ & Employee & $\begin{array}{l}\text { Employe } \\
\mathrm{r}\end{array}$ & Student & $\begin{array}{l}\text { Part time } \\
\text { worker }\end{array}$ \\
\hline & $1.20 \%$ & $27.50 \%$ & $10.40 \%$ & $19.70 \%$ & $21.60 \%$ & $0.30 \%$ & $6.10 \%$ & $1.40 \%$ \\
\hline & Labor & $\begin{array}{l}\text { Un- } \\
\text { employed }\end{array}$ & Retired & Lecturer & & & & \\
\hline & $6.20 \%$ & $4.40 \%$ & $0.90 \%$ & $0.30 \%$ & & & & \\
\hline
\end{tabular}

\subsection{Estimation Method}

Based on Sanquist et al. [32], Baker and Rylatt [16], Kavousian et al. [33], Brounen et al. [17], Bartiaux and Gram-Hanssen [34], and Tiwari [19] the regression methods are the most commonly used to investigate the influence of socio-economic, dwelling and device drivers on domestic electricity consumption that particularly useful for analyzing large datasets. So, in this paper, SPSS 20.0 was used for model estimation. There are three estimation methods were available in SPSS: Generalized Least Squared method (GLS), Asymptotic Distribution Free method (ADF), and Maximization of Likelihood method (ML).Although it is reported that ML fits poorly than others when the data is not continuous or non-normal, this study used 
ML for estimating the model because ML performs well when the sample size is large enough, and it is the most widely applied approach [35].

The SEM was acted in two-phases as portrayed by Anderson and Gerbing, 1988 [36]. 1) A corroborative factor examination (CFA) was determined to check the speculation, at that point Validity evaluations were determined, including united legitimacy, discriminant legitimacy, and build legitimacy. 2) By accepting the estimation model meets integrity of-fit rules, the conjectured auxiliary connections were checked utilizing a basic model, and the most extreme probability strategy was applied to appraise the boundaries. Model integrity of fit was determined utilizing the chi-square test(x2), probability proportion (x2/df), near fit record (CFI) and root mean square blunder of estimation (RMSEA) following the best SEM rehearses as portrayed by Mueller and Hancock, 2008 [37]. The model was considered to fit the data well when the following criteria were met, $\mathrm{x} 2 / \mathrm{df}<3$, CFI $>0.90$, and RMSEA $<0.08$ [38]. Statistical significance was set at a p-value of 0.05 . Different drivers were relied upon to impact the residential electricity utilization, including built environment, responsibility for gadget, family socio-socioeconomics, and person's perspectives. The built environment could impact residential vitality utilization both straightforwardly and by implication through responsibility for gadgets, while it might be likewise affected by both socio-socioeconomics and perspectives.

One of the numerous statistical methods that are proposed to be suitable for analyzing these complex interrelationships among multiple drivers is the Structural Equation Modelling [SEM]. The upsides of SEM are that it does not limit the structure of the model, nor does it confine the type of information, in this manner been viewed as an incredible asset for confirmation of theories [38]. SEM has been frequently utilized in studies that analyze energy consumption. These studies incorporate SEM to investigate how built environment and individual's attitudes interacts with each other, and in turn influence travel behaviors [3]. On the other hand, few studies incorporated SEM to investigate in-house energy consumption. Fig. 3 shows a hypothetical model of SEM to investigate the complicated associations among various drivers that influence domestic electricity consumption in GCMR [3]. First, it assumes that "electric device ownership" directly influences domestic electricity consumption. Second, "attitude towards eco-friendly actions" have both direct effect and indirect effect through "electric device ownership." Third, "concern about environmental issues" influences both "attitude to ecofriendly actions" and "electric device ownerships." Fourth, "family socio-socioeconomics" have sway on residential electricity utilization straightforwardly and by implication on four ways by means of "built environment," "worry about environmental issues," "electric gadget proprietorships," and "disposition to eco-accommodating activities." Fifth, "built environment" affects local electricity utilization legitimately and furthermore in a roundabout way through intermediating factors: "electric gadget possessions," and "demeanor to eco-accommodating activities.

\section{RESULTS AND DISCUSSION}

\subsection{Results of Domestic Electricity Consumption Model}

Table 2 shows the findings of model estimation that explain the Effect of Dwelling physical drivers on domestic electricity consumption, derived from the hypothetical model. The variables that are incorporated in the model include 6 drivers and one latent variable. The latent variable could be explained as a linear function in which a set of observed variables share some common drivers. This means that those set of observed variables would be indicators of the latent variable [38]. Table 2 shows the internal relationships among dwelling physical drivers and common Electrical devices in the study area.

\subsubsection{Dwelling drivers}

Table 2. Effect of dwelling physical Drivers on Domestic Electricity Consumption*

\begin{tabular}{lll}
\hline \hline Variables & Std. Coeff. & t-statistic \\
\hline $\begin{array}{l}\text { Population } \\
\text { density }\end{array}$ & 0.114 & 3.876 \\
\hline $\begin{array}{l}\text { Floor area } \\
\text { of Dwelling }\end{array}$ & 0.133 & 4.712 \\
\hline $\begin{array}{l}\text { Number } \\
\text { of rooms }\end{array}$ & 0.171 & 7.3625 \\
\hline $\begin{array}{l}\text { Number of } \\
\text { bedrooms }\end{array}$ & 0.2052 & 8.835 \\
\hline $\begin{array}{l}\text { Number } \\
\text { of floors }\end{array}$ & 0.038 & 1.3205 \\
\hline \begin{tabular}{l} 
Dwelling age \\
\hline \hline
\end{tabular} & -0.114 & -4.2845 \\
\hline
\end{tabular}

Table 3. Dwelling Physical Drivers and Domestic Electrical devices*

\begin{tabular}{|c|c|c|c|c|c|c|}
\hline \multicolumn{2}{|c|}{ Endogenous variables } & \multirow{2}{*}{$\begin{array}{l}\begin{array}{l}\text { Population } \\
\text { density }\end{array} \\
0.095\end{array}$} & \multirow{2}{*}{$\begin{array}{l}\begin{array}{l}\text { Floor area } \\
\text { of settlement }\end{array} \\
0.19\end{array}$} & \multirow{2}{*}{$\begin{array}{l}\begin{array}{l}\text { Number } \\
\text { of rooms }\end{array} \\
0.0665\end{array}$} & \multirow{2}{*}{$\begin{array}{l}\begin{array}{l}\text { Number } \\
\text { of floors }\end{array} \\
0.0095\end{array}$} & \multirow{2}{*}{$\begin{array}{l}\begin{array}{l}\text { Settlement } \\
\text { age }\end{array} \\
-0.0285\end{array}$} \\
\hline $\begin{array}{l}\text { Number of } \\
\text { air }\end{array}$ & Std. Coeff. & & & & & \\
\hline conditioners & t-statistic & 2.945 & 6.498 & 1.9285 & -0.817 & -0.8455 \\
\hline \multirow{2}{*}{$\begin{array}{l}\text { Number of } \\
\text { electric fans }\end{array}$} & Std. Coeff. & 0.2565 & -0.0475 & 0.1045 & 0.1615 & 0.019 \\
\hline & t-statistic & 8.1605 & 1.6245 & 3.2205 & 5.6145 & -0.4845 \\
\hline $\begin{array}{l}\text { Attitude } \\
\text { toward }\end{array}$ & Std. Coeff. & 0.095 & 0.0475 & 0.0475 & 0 & 0.038 \\
\hline
\end{tabular}




\begin{tabular}{|c|c|c|c|c|c|c|}
\hline $\begin{array}{l}\text { saving } \\
\text { electricity }\end{array}$ & t-statistic & 2.9165 & -1.5485 & -1.349 & -0.1235 & -0.969 \\
\hline
\end{tabular}

The findings showed that the dwelling physical drivers had significant influences on domestic electricity consumption both directly and indirectly. First, the findings indicate the population density has significantly positive effects on electricity consumption as well as the number of air-conditioners and the numbers of electric fans. They may reflect the fact that high population-density areas have inefficient thermal environment, possibly due to the high airtightness; thus, the households own more electric devices and use these devices more frequently to control the room temperature.

Second, the floor area of settlement has a significantly positive effect on domestic electricity consumption since the larger settlement requires more electricity for lighting or more intense use of air-conditioners for room temperature control. The floor area of settlement does not have significant effect on the number of electric fans but has significantly positive effect on the number of air-conditioners. This reflect the fact that air-conditioners are so fixed that their use is limited at specific rooms while electric fans are so movable that they can be used flexibly at any room on the same floor. It should be noted, however, that the number of floors in the settlement does not have significant effect on neither electricity consumption nor number of airconditioners while it has a significantly positive effect on the number of electric fans.

Third, the number of rooms in the settlement has a significantly increase effect on electricity consumption

as well as both air-conditioner ownership and electric fan ownership. This because households with many rooms, household members would use the electric devices separately in each room, thus leading to higher electricity use. We identified that, with only one or two rooms used significantly less electricity than five room houses. Similarly, Bedir et al. [38] found that the number of rooms in Dutch homes, and the number of hobby and study rooms were significantly positively correlated with electricity consumption.

Fourth, we noted that the number of bedrooms had the largest total effect among dwelling physical Drivers. We observed that load peaks of five bedroom were over three times more than those of two bed-room households.

Fifth, the settlement age has a negative effect on electricity consumption. This because older settlements are typically less effective in shutting the heat from outside, which may lead to more intensive use of airconditioners or fans, and residents in older settlements tend to use older and ineffective electric devices, which would lead to more electricity consumption. In particular, the study found that new buildings (19802012) had higher electricity consumption than old buildings (pre 1980).

\subsubsection{Socio-economic drivers}

Table 4. Impact of Socio-Economic forces on Domestic Electricity Consumption*

\begin{tabular}{lcc}
\hline \hline Variables & Std. Coeff. & t-statistic \\
\hline Number of occupants & 0.13794 & 3.896805 \\
\hline Number of adults in a household & 0.038 & 1.0735 \\
\hline Number of children in a household & -0.0475 & -1.653 \\
\hline Monthly household income & 0.3895 & 11.115 \\
\hline Number of air conditioners owned & 0.38 & 13.87 \\
\hline Attitude towards saving electricity & -0.019 & -1.5295 \\
\hline Concern about environmental issues & 0.0285 & 1.064 \\
\hline \hline
\end{tabular}

Table 5. Relation among Socio-Economic Drivers, Physical Dwelling, and Domestic Devices*

\begin{tabular}{lllll}
\hline \hline \multicolumn{2}{l}{ Endogenous variables } & $\begin{array}{l}\text { Number of adults in a } \\
\text { household }\end{array}$ & $\begin{array}{l}\text { Number of children in } \\
\text { a household }\end{array}$ & $\begin{array}{l}\text { In } \\
\text { income) }\end{array}$ \\
\hline $\begin{array}{l}\text { Electricity } \\
\text { consumption }\end{array}$ & $\begin{array}{l}\text { Std. } \\
\text { Coeff. }\end{array}$ & -0.038 & -0.019 & 0.228 \\
\cline { 2 - 6 } & t-statistic & -1.216 & -0.855 & 7.638 \\
\hline $\begin{array}{l}\text { Number of } \\
\text { air } \\
\text { conditioners }\end{array}$ & $\begin{array}{l}\text { Std. } \\
\text { Coeff. }\end{array}$ & -0.1425 & -0.019 & 0.247 \\
\hline $\begin{array}{l}\text { Number of } \\
\text { electric fans }\end{array}$ & t-statistic & -4.085 & -0.627 & 7.5525 \\
\hline
\end{tabular}




\begin{tabular}{|c|c|c|c|c|}
\hline & $\mathrm{t}$-statistic & -0.1235 & -1.254 & 8.1605 \\
\hline \multirow[t]{2}{*}{$\begin{array}{l}\text { Population } \\
\text { density }\end{array}$} & $\begin{array}{l}\text { Std. } \\
\text { Coeff. }\end{array}$ & -0.076 & -0.133 & 0.171 \\
\hline & t-statistic & -2.356 & -4.1895 & 5.2155 \\
\hline \multirow[t]{2}{*}{$\begin{array}{l}\text { Floor area of } \\
\text { settlement }\end{array}$} & $\begin{array}{l}\text { Std. } \\
\text { Coeff. }\end{array}$ & 0.2755 & 0.0285 & 0.1425 \\
\hline & t-statistic & 8.5975 & -0.836 & 4.3985 \\
\hline \multirow[t]{2}{*}{$\begin{array}{l}\text { Number } \\
\text { rooms }\end{array}$} & $\begin{array}{l}\text { Std. } \\
\text { Coeff. }\end{array}$ & 0.3705 & 0.0475 & 0.095 \\
\hline & t-statistic & 12.16 & -1.5105 & 3.1255 \\
\hline \multirow[t]{2}{*}{ Settlement age } & $\begin{array}{l}\text { Std. } \\
\text { Coeff. }\end{array}$ & 0.3325 & -0.076 & -0.114 \\
\hline & t-statistic & 10.64 & -2.4795 & -3.743 \\
\hline
\end{tabular}

The findings show that the household sociodemographic influence the domestic electricity consumption, both directly and indirectly, via built environment, concern about environmental issues, and the ownership of electric devices.

We analyzed the normal every day yearly electricity utilization per unit floor territory for homes involved by one, two, three or at least four tenants and found that family units with at least four inhabitants devoured biggest measure of electricity and there was a little distinction between the utilization in families with a few inhabitants. We perceived that a five-part family would have $23 \%$ greater electricity consumption contrasted with a two-part family. At that point, we found that the electricity utilization per individual diminished as the quantity of tenants expanded, this impact was huger in huge residences, as the quantity of inhabitants per abiding get littler. Comparative discoveries were found by Gram-Hanssen [34].

Month to month salary affects electricity utilization, both legitimately and in a roundabout way by means of forced air system proprietorship and electric fan possession. Specifically, We recognized that family units with wages more than 2400 EGP every month utilize 2.5 occasions more electricity on normal in the nights than low-salary families (under 900 EGP per month).We believed that higher pay family units ordinarily have a more prominent number of tenants

and bigger homes, just as an assorted scope of electric gadgets. Different examinations [32] [15] [18] have additionally distinguished a factually huge impact of house hold pay on electricity utilization, yet confirmed that electricity request rises generally little with pay, recommending that electricity utilization in low and high salary family units doesn't vary much since electricity, in any event at the levels utilized, is a need for the two gatherings.

The quantity of kids and the quantity of grown-ups have negative direct impact on electricity utilization although they are less huge. The Presence of kids and its effect on electricity utilization was demonstrated to be huge. We confirmed that grown-ups living with kids expended extensively more electricity than those living alone or with different grown-ups. Especially, Households with youngsters expended just about one fifth more electricity than families without kids, and this impact was more grounded when the age of the kids expanded.We accepted this was on the grounds that more seasoned kids observe more TV, use PCs, and are visit clients of gaming gadgets with comparative discoveries of Gram-Hanssen [34]. They found a Significant Effect of Family Composition (Teenagers, Adults and Elderly People, Presence of Children) on electricity utilization in private structures.

\subsubsection{Device drivers}

Table 7. Estimation Result of Domestic Electricity Consumption Model - Household Attitudes*

\begin{tabular}{llll}
\hline \hline Endogenous variables & & $\begin{array}{l}\text { Attitude toward saving } \\
\text { electricity }\end{array}$ & \multicolumn{1}{c}{$\begin{array}{l}\text { Concern about environmental } \\
\text { issues }\end{array}$} \\
\hline $\begin{array}{l}\text { Electricity } \\
\text { consumption }\end{array}$ & Std. Coeff. & -0.038 & - \\
\hline Number of air conditioners & t-statistic & -1.5295 & - \\
\cline { 2 - 4 } & Std. Coeff. & 0.0285 & 0.019 \\
\cline { 2 - 4 } $\begin{array}{l}\text { Number of } \\
\text { electric fans }\end{array}$ & St-statistic & -0.9405 & -0.5605 \\
\hline Attitude toward & t-statistic & 0.057 & 0.0665 \\
saving electricity & Std. Coeff. & - & 2.3655 \\
\hline \hline
\end{tabular}

The discoveries recognized that both the quantity of forced air systems and the quantity of electric fans have solid positive effects on electricity utilization. The all-out impact of the quantity of climate control systems is about equivalent with the impact of family unit pay. Electrical gadgets made a noteworthy commitment to a household's electricity utilization. This effect not just identifies with the quantity of each kind of gadget possessed, yet in addition to the force request and recurrence of utilization. The noteworthy impact of the utilization of electric space cooling via cooling and ventilation frameworks has been broadly endorsed in comparative examination [16] [45] [26].

It should be noted that the impact of the air-conditioner ownership is significantly greater than that of the electric fan where a null hypothesis, the former is equal to the latter, is rejected at $95 \%$ confidence level with the statistical test. This is because the air-conditioners are more energy consuming than the electric fans. 
Next, the concern towards environmental issues did not have significant effect on the attitude towards saving electricity. This could propose that the motivation for households to save the use of electricity is not attributed to the concern about environmental issues. The findings also show that the attitude towards saving electricity do not have significant effect on electricity consumption. However, note that the attitude towards saving electricity has positive impact on electric fan ownership. The two attitudinal drivers, attitude towards saving electricity and concern about environmental issues, have small total effect on electricity consumption.

\section{CONCLUSION}

This paper permits a superior handle of those drivers that fundamentally cause electricity utilization and those for which impacts are uncertain and need further examination. Under-standing the impacts off entertainer examine bolster both the accomplishing of adequate vitality strategy and to estimate and plan electricity utilization and adjusting their negative effects on environmental change. The findings of Giza case study suggest that a design of built environment could participate in managing the domestic electricity consumption in developing metropolitan regions as well as in advanced metropolitan regions which will reduce the negative impacts on climate change ultimately. For instance, the findings specify that the compactness of residential area would rise domestic electricity consumption, opposing to the current indications from advanced metropolitan regions.

The exploration suggestions are introduced connecting abiding and tenant financial factors and electrical boundaries: Dwelling number of rooms, which was utilized as an intermediary for staying size, was found to emphatically impact complete electricity utilization. Loft residences, which are relatively littler and have less tenants and apparatuses, devoured the least electricity when contrasted with other dwelling types. Family social class was noteworthy with Higher Professionals devouring more electricity than center or lower classes, mirroring a potential pay impact.

\section{REFERENCES}

[1] L. KJ., "Carbon reduction in existing buildings: a transdisciplinary approach," Build ResInf, vol. 38, no. 1, p. 1-11, 2010

[2] L. R. Oreszczyn T, "Challenges for energy and buildings research: objectives, methods and funding mechanisms," Build Res Inf, vol. 38, no. 1, p. 107-22, 2010.

[3] T. Osman, P. Divigalpitiya and T. Arima, "The impact of Built Environment Characteristics on Metropolitans Energy Consumption: an Example of Greater Cairo Metropolitan Region.," Buildings, vol. $6, \quad$ no. $2, \quad 2016 . \quad$ DOI: 10.3390/buildings6020012.

[4] UN-HABITAT, "State of the world's cities 2012/2013: Prosperity of cities," United Nations Human Settlements Programme, Nairobi, 2012.

[5] U. Nations, "City planning will determine pace of global warming," United Nations, 2007.
[6] T. Osman, P. Divigalpitiya and T. Arima, "Using the SLEUTH Urban Growth Model to Simulate the Future Policy Scenarios " International Journal of Urban Sciences, 2016. http://dx.doi.org/10.1080/12265934.2016.1216327

[7] F. Krass, "Megacities and global change: Key priorities," Geographical Journal, vol. 173, no. 1, p. 79-82, 2007.

[8] T. Osman, T. Arima and P. Divigalpitiya, "Measuring urban Sprawl patterns in Greater Metropolitan Cairo Region," Journal of the Indian Society of Remote Sensing, vol. 44, no. 2, pp. 287 295, 2016

[9] T. Osman, P. Divigalpitiya and T. Arima, "Effect of Urban Development Patterns on Traffic-Related $\mathrm{CO}_{2}$ Emissions in Greater Cairo Metropolitan Region," 都市 - 建築学研究: 九州大学, vol. 29, no. 1, pp. 29-38, 2016.

[10] E. \&. N. I. T. Holden, "Three challenges for the compact city as a sustainable urban form: Household consumption of energy and transport in eight residential areas," Urban Studies, vol. 42, no. 12, p. 2145-2166, 2005.

[11] M. N. P. B. Cramer JC, "Social and engineering determinants and their equity implications in residential electricity use," Energy, vol. 10, no. 12, p. 1283-91, 1985.

[12] O. \&. L. I. Guerra-Santin, "Occupants' behaviour: determinants and effects on residential heating consumption," Building Research \& Information, vol. 38, no. 3, pp. 318-338, 2010.

[13] R. R. F. Ewing, "The impact of urban form on US residential energy use," Housing Policy Debate, vol. 19, pp. 1-30, 2008.

[14] S. L. a. R. T. J. O'Doherty, "Energy-Using Appliances and Energy-Saving Features: Determinants of Ownership in Ireland," Applied Energy, vol. 85, no. 7, pp. 650-662, 2008.

[15] G. J. D. M. A. W. B. N. Y. Yohannis, "Real-life energy use in the UK: how occupancy and dwelling characteristics affect domestic electricity use," Energy and , vol. 40, p. 1053-1059, 2008.

[16] R. R. Baker KJ, "Improving the prediction of UK domestic energy-demand using annual consumption-data," Appl. Energy, vol. 85, no. 6, p. 475-82, 2008.

[17] K. Q. J. Brounen D, "Residential energy use and conservation: economics and demographics.," Eur. Econ. Rev., vol. 56, no. 5, p. 931-45, 2012.

[18] C. H. M. D. M. Louw K, "Determinants of electricity demand for newly electrified lowincome African households," Energy Policy, vol. 36 , no. 8, p. 2812-8, 2008.

[19] T. P., "Architectural, demographic, and economic causes of electricity consumption in Bombay," J Policy Model, vol. 22, no. 1, p. 81-98, 2000.

[20] G. K. NdiayeD, "Principal component analysis of the electricity consumption in residential dwellings," Energy Build, vol. 43, no. 2, p. 44653, 2011.

[21] M. S. L. v. L. S. F. Rooijers, "Slingerland, Energie en gedrag in dewoning," VROM, DG, Wonen, CE, rapport, , Delft, 2003. 
[22] E. R. Center, "Energy Research Center," MONITWeb, 2009. [Online]. Available: http://www.energie.nl/index2. html?stat/index.html.

[23] L. S. Leahy E, "Energy use and appliance ownership in Ireland," Energy Policy, vol. 38, no. 8, p. 4265-79, 2010.

[24] P. Parti M, "The total and appliance-specific conditional demand for electricity in the household sector," Bell J Econ, vol. 11, no. 1, p. 309-21, 1980.

[25] I. N. M. a. P. D. Mansouri, "Energy consumption in UK households: impact of domestic electrical appliances," Applied Energy, vol. 54, pp. 211-285, 1996.

[26] ODYSSEE, "Energy Efficiency Profile: Energy Netherlands," 2008.

[27] T. Osman, T. Arima and P. Divigalpitiya, "Driving Factors of Urban Sprawl in Giza Governorate of Greater Cairo Metropolitan Region Using AHP method," Journal of Land Use Policy, Land Use Policy, 58, pp.21-31. Available at: http://dx.doi.org/10.1016/j.landusepol.2016.07.013.

[28] T. Osman, P. Divigalpitiya and T. Arima, "Driving Factors of Urban Sprawl in Giza Governorate of the Greater Cairo Metropolitan Region Using a Logistic Regression Model.," International Journal of Urban Sciences, vol. 20, no. 2, 2016. DOI: 10.1080/12265934.2016.1162728.

[29] T. Osman, P. Divigalpitiya and T. Arima, "Effect of Governmental Housing Regulations on the Egyptian Housing Market: Focusing on Greater Cairo Metropolitan Region," 都市・建築学, vol. 28, no. 2, pp. 1-9, 2015.

[30] M. E. Araby, "Urban growth and environmental degradation: The case of Cairo, Egypt," Cities, vol. 19, no. 6, p. 389-400, 2002.

[31] D. S. S. B. J. M. Z.Y. Yin, "Changes in urban built-up surface population distribution patterns during 1986-1999: a cast study of Cairo, Egypt," Comput. Environ. Urban Syst., vol. 29, p. 595616, 2005.

[32] O. H. B. ,. B. A. Sanquist TF, "Life style factors in U.S. residential electricity consumption," Energy Policy, vol. 42, p. 354-64, 2012.

[33] R. R. a. F. M. Kavousian A, "Determinants of residential electricity consumption: using smart meter data to examine the effect of climate, building," Energy, vol. 55, p. 184-94, 2015.

[34] G.-H. K. Bartiaux F, "Socio-political factors influencing household electricity consumption: a comparison between Denmark and Belgium," in Proceedings of the ECEEE, European Council for an Energy Efficient Economy, 2005.

[35] J. J. \&. B. T. M. Hox, "An introduction to structural equation modeling," Fam. Sci. Rev., vol. 11, pp. 354-373, 1998.

[36] J. C. \&. G. D. W. Anderson, "Structural equation modeling in practice:A review and recommended two-step approach," Psychological Bulletin, vol. 103, no. 3, p. 411-423, 1988.

[37] R. O. \&. H. G. R. Mueller, Best practices in structural equation modeling, Louisville, KY: SAGE Publications, Inc., 2008, p. 488-508.

[38] L. \&. B. P. M. Hu, "Cutoff criteria for fit indexes in covariance struc-ture analysis: Conventional criteria versus new alternatives," Structural EquationModeling: A , vol. 6, no. 1, pp. 1-55, 1999. 